\title{
UPAYA MENINGKATKAN HASIL BELAJAR PENDIDIKAN AGAMA ISLAM PADA MATERI POKOK INFAK HARTA DILUAR ZAKAT MELALUI MODEL PEMBELAJARAN KOOPERATIF TIPE STAD
}

\author{
M. Zulham Hidayah Saragih \\ Sekolah Menengah Pertama Al-Hidayah Medan, \\ Universitas Islam Negeri Sunan Kalijaga Yogyakarta \\ saragihhidayah@gmail.com
}

\begin{abstract}
Abstrak: Penelitian ini bertujuan untuk mengetahui peningkatan hasil belajar pendidikan agama islam pada materi pokok infak harta diluar zakat pembahasan Sedekah, Hibah, dan Hadiah di kelas VIII SMP AL-Hidayah Medan dengan menerapkan model pembelajaran Kooperatif Tipe STAD. Penelitian ini merupakan penelitian tindakan kelas yang dilaksanakan dalam 2 siklus yang meliputi kegiatan perencanaan, pelaksanaan, observasi dan refleksi. Sedangkan untuk mengetahui kemampuan siswa, peneliti menggunakan tes hasil belajar siswa secara individu.Yang menjadi subjek dalam penelitian ini adalah siswa kelas VIII SMP AL-Hidayah Medan yang berjumlah 39 siswa yang terdiri dari 23 siswa laki - laki dan 16 siswa perempuan. Sebelum pemberian tindakan, persentase ketuntasan klasikal siswa dilihat dari pree test diperoleh sebesar 25,64 \% (10 siswa). Setelah pemberian tindakan dengan menggunkan model pembelajaran Kooperatif tipe STADl. Tes hasil siswa pada siklus I memperoleh persentase klasikalnya sebesar 53,84 \% (21 Siswa). Sedangkan setelah dilakukan perbaikan dari siklus I ke siklus II maka nilai persentase ketuntasan klasikalnya meningkat sebesar 87,17\% (34 siswa). Jadi peningkatan nya mencapai $33.33 \%$ dari siklus I ke siklus II. Dari hasil penelitian tindakan kelas ini, maka peneliti menyimpulkan bahwa adanya peningkatan hasil belajar pendidikan agama islam dan merekomendasikan pada pelaksana pembelajaran untuk mengerjakan materi dengan mengembangkan model pembelajaran Kooperatif Tipe STAD
\end{abstract}

Kata Kunci: Pendidikan Agama Islam, Belajar, Model Pembelajaran, Kooperatif tipe STAD

\begin{abstract}
This study aims to determine the increase in the results of learning Islamic religious education in the subject matter of infaq assets outside the almsgiving discussion of Alms, Grants, and Gifts in class VIII of Medan AL-Hidayah Middle School by applying the Cooperative Type STAD learning model. This research is a classroom action research conducted in 2 cycles which includes planning, implementing, observing and reflecting activities. Whereas to find out the ability of students, researchers use individual student learning outcomes tests. The subjects in this study were the eighth grade students of Medan AL-Hidayah Middle School, amounting to 39 students consisting of 23 male students and 16 female students. Before giving action, the percentage of students' classical completeness seen from the pree test was obtained at $25.64 \%$ (10 students). After giving action by using the STADl type cooperative learning model. Student test results in cycle I get a classic percentage of 53.84\% (21 students). Whereas after the improvement from cycle I to cycle II, the percentage of classical completeness was increased by $87.17 \%$ (34 students). So the increase reached 33.33\% from cycle I to cycle II. From the results of this class action research, the researchers concluded that there was an increase in the results of learning Islamic religious education and recommending the implementers of learning to work on the material by developing a Cooperative Type STAD learning model
\end{abstract}

Keywords: Islamic Education, Learning, Learning Models, Cooperative type STAD

\section{PENDAHULUAN}

Pendidikan islam adalah bimbingan jasmani dan rohani berdasarkan hukum islam menjuju terbentuknya kepribadian utama menurut ukuran agama. Ada beberapa istilah pendidikan dalam islam, anataranya: Istilah Tarbiyah, istilah tarbiyah digunakan untuk menyatakan usaha pendidikan dalam menumbuh kembangkan seluruh potensi peserta didik agar benar - benar menjadi makhluk yang 
beragama dan berbudaya. Istilah ta'lim, maka pendidikan islam yang tidak lain bertujuan untuk mewariskan dan menginternalisasikan kandungan dan nilai - nilai al-quran kepada manusia, sehingga dengan demikian kegiatan tersebut dapat dekatakan sebagai kegiatan ta'lim. Istilah ta'dib, Ta'dib berasal dari kata addaba yang berarti mendidik.

Pendidikan agama Islam adalah upaya sadar dan terencana dalam menyiapkan peserta didik untuk mengenal, memahami, menghayati, hingga mengimani, ajaran agama islam, dibarengi dengan tuntunan untuk menghormati penganut agama lain dalam hubungannya dengan kerukunan antar ummat beragama hingga terwujud kesatuan dan persatuan bangsa. Hal ini sejalan dengan undang-undang Nomor 20 tahun 2003 tentang sistem pendidikan Agama Islam bahwa pendidikan agama dimaksudkan untuk membentuk peserta didik menjadi manusia yang beriman dan bertaqwa kepada tuhan yang maha Esa serta berakhlak mulia. (Depdiknas, 2003)

Tujuan pendidikan agama, yaitu untuk berkembangnya kemampuan perserta didik dalam mengembangkan, memahami dan mengamalkan nilai-nilai agama islam, penguasaan ilmu pengetahuan, teknologi dan seni. Oleh karena itu pendidikan berperan penting dalam kecakapan hidup manusia. Pendidikan agama Islam di SMP bertujuan untuk menumbuhkan dan meningkatkan keimanan, melalui pemberian dan pemupukan pengetahuan, penghayatan, pengamalan, serta pengamalan peserta didik tentang agama Islam, menjadi manusia muslim yang terus berkembang dalam keduniaan, ketaqwaan kepada Allah SWT, Serta berakhlak mulia dalam kehidupan pribadi, bermasyarakat, berbangsa dan bernegara, serta untuk dapat melanjutkan pada jenjang pendidikan yang lebih tinggi. Dalam pandangan Islam pun, belajar merupakan kewajiban bagi setiap orang beriman agar memperoleh ilmu pengetahuan dalam rangka meningkatkan derajat kehidupan mereka. Hal ini dinyatakan dalam surah Mujadalah ayat 11 yang berbunyi:

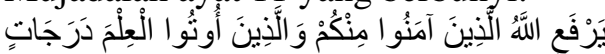

“... nicaya Allah akan meninggikan beberapa derajat kepada orang-orang beriman dan berilmu.."

Dari surah mujadallah ayat 11 terdapat janji allah yang akan meninggikan derajat orang orang yang diberikan ilmu pengetahuan. Kata yarfaillahu ladzina amanu, ditafsirkan oleh al- tarbawiy sebagai janji Allah untuk mengangkat derajat yang telah memuliakan dan memiliki ilmu diakhirat pada tempat yang khusus sesuai dengan kemuliaan dan ketinggian derajatnya, (Abudin Nata, 2001: 151).

SMP Al-Hidayah Medan adalah salah satu SMP di Medan yang memiliki beberapa permasalahan antara lain terjadi kecurangan pada siswa yang terlihat pada saat ulangan, banyaknya siswa Smp yang kesulitan dalam mengerjakan soal-soal pada pembelajaran pendidikan agama Islam materi infak harta diluar zakat serta hasil belajar yang belum memenuhi Kriteria Ketuntasan Minimal $(\mathrm{KKM})$. Hal ini merupakan permasalahan yang ada di kelas dan harus segera diselesaikan. Salah satu cara yang ditempuh untuk menyelesaikan masalah ini adalah dengan penggunaan strategi pembelajaran kooperatif.

Slavin (2005: 1) menerangkan bahwa pembelajaran kooperatif dapat diaplikasikan untuk semua kelas, yaitu: kelas khusus untuk anak berbakat, kelas pendidikan khusus, kelas dengan kecerdasan rata-rata dan sangat diperlukan dalam kelas heterogen dengan berbagai tingkat kemampuan. Slavin (2005: 1) menambahkan bahwa pembelajaran kooperatif dapat diaplikasikan untuk semua kelas dan dapat menumbuhkan motivasi dari dalam diri siswa. Slavin (2005: 4-8) Dalam kelas kooperatif, para siswa diharapkan dapat saling membantu, saling mendiskusikan dan berargumentasi untuk mengasah pengetahuan yang mereka kuasai saat itu dan menutup kesenjangan dalam pemahaman masing masing.

Pembelajaran kooperatif lebih dari sekedar belajar kelompok karena dalam model pembelajaran ini harus ada struktur dorongan dan tugas yang bersifat kooperatif sehingga memungkinkan terjadi interaksi secara terbuka dan hubungan - hubungan yang bersifat interdependensi efektif antara anggota kelompok. Anita lie (2010: 29) mengungkapakan bahwa pembelajaran kooperatif tidak sama dengan sekedar belajar dalam kelompok, Ada lima unsur dalam pembelajaran kooperatif yang membedakannya dengan pembagian kelompok yang dilakukan asal-asalan, yaitu: saling ketergantungan pasif, tanggung jawab perorangan, tatap muka, komunikasi antar anggota, dan evalusi proses kelompok. Dapat disimpulkan dari berbagai paparan tersebut bahwa pembelajaran kooperatif merupakan pembelajaran yang dapat 
diterapkan di semua kelas dan menumbuhkan motivasi, kemandirian dan bakat siswa melalui kerjasama kelompok dalam mencapai tujuan bersama (belajar).

Slavin (2005: 11) mengatakan bahwa pembelajaran kooperatif memiliki lima jenis yaitu: (1) Students Team Achievement Division/ STAD, (2) Team Game Tournament/ TGT, (3) Jigsaw II, (4) Team Accelerated Instruction/ TAI, (5) Cooperative Integrated Reading and Composition/CIRC. Dari kelima jenis pembelajaran kooperatif tersebut, STAD (Student Teams Achievement Divisions) yaitu pembelajaran secara berkelompok beranggotakan 4-6 orang, merupakan gabungan dengan tingkat kemampuan heterogen. dinilai dapat mengatasi permasalahan pembelajaran di kelas. Ide utama pembelajaran metode STAD adalah untuk memotivasi siswa agar saling membantu dalam memahami sebuah materi pelajaran dan saling membantu dalam menyelesaikan masalah.

Agar mendapatkan penghargaan dari guru maka anggota tim harus memperoleh nilai yang tinggi dalam evaluasi yang diberikan. Oleh karena itu kerjasama tim dan saling memotivasi akan mengantarkan siswa pada kesuksesan. Lima komponen pembelajaran kooperatif tipe STAD menurut Slavin adalah: (1) penyajian kelas, (2) kegiatan kelompok, (3) kuis, (4) skor kemajuan (perkembangan) individu dan (5) penghargaan kelompok. Belajar merupakan suatu proses yang tidak dapat dilihat dengan nyata, proses itu terjadi di dalam diri seseorang yang sedang mengalami belajar. Menurut skinner, belajar adalah suatu prikalu, pada saat orang belajar, maka responnya menjadi lebih baik. Sebaliknya, bila ia tidak belajar, maka responnya menurun, kemudian belajar merupakan kegiatan kompleks (Mujiono, 2006: 130). Hilgard mengungkapkan bahwa belajar itu adalah proses perubahan melalui kegiatan atau prosedur pelatihan baik latihan didalam laboratorium maupun didalam lingkungan alamiah (Sanjaya, 2010: 112).

Menurut purwanto (2010: 54) mengemukakan hasil belajar yaitu perubahan perilaku yang terjadi setelah mengikuti proses belajar mengajar sesuai dengan tujuan pendidikan, dan bahwa hasil belajar adalah perubahan perilaku secara keseluruhan bukan hanya salah satu aspek potensial kemanusiaan saja. Hasil belajar pada hakikatnya tersirat dalam tujuan pengajaran. Oleh sebab itu hasil belajar siswa disekolah siswa dan kualitas pengajaran. Menurut Bloom, mengatakan ada tiga variabel utama dalam teori belajar disekolah, yakin: karakteristik individu, kualitas pengajaran, dan hasil belajar siswa (Sabri. A,2010: 46).

Bloom (1956: 7) mengungkapkan bahwa "Our original plans called for a complete taxonomy in three major parts, the cognitive, the affective and the psychomotor domains" atau dinyatakan bahwa pada awalnya taksonomi terdiri dari tiga ranah yaitu kognitif, afektif dan psiko-motorik. Dari ketiga ranah tersebut terdapat beberapa tingkatan. Dalam penelitian ini hasil belajar yang diukur ada pada ranah kognitif dengan tingkatan yang terdiri atas: (1) pengetahuan, (2) pemahaman, (3) penerapan, (4) analisa, (5) sintesa dan (6) evaluasi.

\section{METODE}

Jenis penelitian ini adalah penelitian tindakan kelas (classroom action research). Seiring dengan penelitian ini, maka penelitian ini memiliki tahap - tahap penelitian berupa siklus, adapun penelitian tindakan kelas (PTK) menurut Burns dalam wina sanjaya Wina Sanjaya (2011: 25), adalah penelitian berbagai fakta yang ditemukan untuk memecahkan masalah dalam situasi sosial untuk memecahkan masalah dalam situasi sosial untuk meningkatkan kualitas tindakan yang dilakukan dengan melibatkan kolaborasi dan kerjasama para peneliti dan prakris. Sebelum penelitian dilaksanakan, peneliti terlebih dahulu melakukan observasi kelas untuk mengetahui kondisi kelas, interaksi antara guru dengan siswa, serta berupaya menemukan berbagai permasalahan selama proses pembelajaran berlangsung. Selanjutnya dicari akar penyebab permasalahan dan rencana penyelesaian yang akan menjadi acuan awal penelitian. Hasil belajar siswa diketahui dari hasil tes atau ulangan harian setiap kompetensi dasar kemudian dilakukan analisis.

Penelitian ini dilaksanakan di SMP AlHidayah Medan pada siswa kelas VIII yang beralamat dijalan letda sujono medan tembung. Penelitian ini dilaksanakan pada semester genap tahun ajaran 2014-2015 Subjek penelitian ini adalah siswa kelas VIII-B SMP Al-Hidayah Medan, yang berjumlah sebanyak 39 orang siswa yang diamati tingkah lakunya di saat pembelajaran berlangsung. Kelas VIII B terdiri dari 24 siswa laki-laki dan 15 siswa perempuan. Di kelas ini prestasi siswa, latar belakang 
keluarga dan kemampuan belajar siswa sangat beragam. Sampel dipilih dengan menggunakan teknik purposive sampling yaitu teknik pengambilan sampel sumber data dengan pertimbangan tertentu. Sampel dalam penelitian ini berfungsi untuk mendapatkan informasi yang maksimum, bukan untuk digeneralisasikan (Sugiyono, 2007: 301). Pertimbangan dalam penentuan sampel ini berdasarkan pada keberagaman nilai siswa dan kondisi kelas VIII B yang kurang dinamis dalam pembelajaran.

Penelitian ini merupakan penelitian tindakan kelas yang berupaya untuk mengubah kondisi kelas sekarang ke arah kondisi yang diharapkan menjadi lebih baik dan dinamis. Dalam penelitian ini peneliti sekaligus menjadi guru namun juga tetap melaksanakan pola kerja sama (kolaborasi) terutama dalam melaksanakan penelitian (melaksanakan tindakan, observasi, merekam data, evaluasi dan refleksi). Untuk itu, peneliti berkolaborasi dengan guru serumpun.

Penelitian tindakan kelas ini menerapkan model spiral dari Kemmis dan Taggart yang dikemukakan oleh Mulyasa (2011: 182) yang membagi prosedur penelitian tindakan dalam empat tahap kegiatan pada satu putaran (siklus) yaitu perencanaan, tindakan observasi dan refleksi dalam suatu spiral yang saling terkait. Tindakan dan keberhasilan pada siklus pertama harus diobservasi, dievaluasi dan kemudian direfleksi untuk merancang tindakan pada siklus kedua dan begitu seterusnya hingga diperoleh peningkatan kemajuan yang diinginkan.

Penelitian ini terdiri atas rangkaian empat kegiatan utama yang dilakukan dalm siklus berulang. Empat kegiatan utama yang ada pada setiap siklus, yaitu: Perencanaan, Tindakan, Pengamatan, Dan Reffleksi (Asrul dan Amiruddin, 2013: 105). Tiap siklus yang dilaksanakan sesuai dengan perubahan yang akan dicapai. Adapun dalam penelitian ini dilaksanakan dalam dua siklus, setiap siklus terdiri dari dua pertemuan. Tahapan penelitian tindakan sebagai berikut.

Pada tahap persiapan, peneliti melakukan observasi tentang perilaku siswa terutama motivasi dan kemandirian siswa, dan mengamati hasil belajar siswa untuk menentukan pembagian kelompok belajar. Observasi awal digunakan untuk mengetahui tingkat motivasi dan kemandirian siswa dalam pembelajaran dan sebagai acuan peningkatan yang terjadi setelah penggunaan STAD.
Observasi ini juga dibutuhkan untuk menentukan langkah-langkah dalam pembelajaran kooperatif tipe STAD. Selain observasi kelas, dibutuhkan dokumentasi nilai siswa untuk acuan pembentukan kelompok belajar STAD. Langkah selanjutnya setelah observasi adalah menentukan rencana tindakan berupa tindakan siklus1.

\section{Siklus I}

Pada tahap penelitian ini, masalah yang diduga adalah rendahnya hasil belajar pendidikan agama siswa. Temuan awal penelitian ini adalah siswa mengalami kesulitan dan menyelesaikan dan memecahkan permasalahan serta soal - soal dalam pelajaran tersebut. Sebelum melakukan perencanaan penelitian memberikan tes awal kepada siswa. Tes awal diberikan untuk mengetahui tingkat penguasaan siswa terhadap materi pokok infak harta diluar zakat, serta untuk memahami dan mengetahui kesulitan yang dialami siswa dalam menyelesaikan soal-soal yang diberikan. Perencanaan;Guru mempersiapkan rencana pelaksanaan pembelajaran (RPP) untuk 2 kali pertemuan, dengan materi infak harta diluar zakat yang berisikan, Sedekah, Hibah, Hadiah,Persamaan,Perbedaan dan Manfaat serta Mempraktikkannya. Guru memberikan informasi kepada siswa tentang materi yang akan mereka pelajari, tujuan pembelajaran, dan pemberian motivasi agar siswa tertarik pada materi. Guru membentuk siswa kedalam kelompok yang sudah direncanakan. Guru mensosialisasikan kepada siswa tentang model pembelajaran yang digunakan dengan tujuan agar siswa mengenal dan memahaminnya. Guru memberikan apersepsi yang berkaitan dengan materi yang akan dipelajari. Guru meminta guru lain sebagai observer untuk mengamati berlangsungnya PTK yang akan dilaksanakan. Guru menentukan waktu atau jadwal pelaksanaan PTK.

Pelaksanaan; Kegiatan yang dilakukan pada tahap ini adalah melakukan pembelajaran seperti yang tersusun dalam rencana pembelajaran (RPP) sedangkan guru mengamati kegiatan yang berlangsung. Pengamatan; Pengamatan dilakukan pada saat proses pelaksanaan pembelajaran berlangsung dilakukan oleh obsever, adapun aspek yang diamati adalah: Pengamatan terhadap siswa dalam mengemukakan pendapat pada waktu pelaksanaan pembelajaran. Pengamatan terhadap guru dalam melaksanakan 
pembelajaran dengan menggunakan metode stad. Refleksi; Setelah proses pembelajaran siklus I selesai, diadakan refleksi tentang: Keaktifan siswa dalam mengikuti proses pembelajaran dengan menggunakan metode STAD yang meliputi melaksanakn kegiatan sistematis, berinteraksi satu sama lain, keberanian siswa dalam bertanya maupun menyampaikan gagasan. Cara guru dalam melaksanakan pembelajan dengan menggunakan metode STAD.

\section{Siklus II}

Pada siklus ini dilakukan perbaikan pada metode Stad sebagai upaya meningkatkan hasil belajar siswa dalam pelajaran pendidikan agama islam, terutama materi yang diperbaiki pada siklus ini ialah, sedekah, hibah, dan hadiah. Indikator keberhasilan diukur dari kaulitas siswa melaksanakan proses pembelajaran. Persiapan pada siklus II ini meliputi merevisi RPP, mempersiapkan lembar penilaian, membuat kelompok baru dengan memperhatikan perbedaan tingkat prestasi siswa (tinggi, sedang dan rendah) dan jenis kelamin dan mempersiapkan soal tes. Tahap kedua adalah pelaksanaan tindakan yang dilakukan sebagaimana pelaksanaan tindakan pada siklus pertama. Pembelajaran dilaksanakan mengacu pada RPP yang telah dibuat. Dari siklus II ini diharapkan ada peningkatan hasil belajar siswa. Tahap ketiga adalah observasi yang dilaksanakan dengan tes kemampuan siswa. Tahap terakhir adalah refleksi dimana dalam siklus II ini digunakan sebagai pembanding hasil dari siklus I. Apabila belum terjadi peningkatan yang signifikan maka siklus bisa diulang.

Instrumen pengumpulan data dalam penelitian ini meliputi: (1) dokumentasi yang merupakan dokumentasi nilai siswa sebagai dasar pembagian kelompok STAD dan pengukuran keberhasilan penelitian. Setelah kegiatan dalam kelompok berjalan, kemudian dilakukan tes tertulis untuk mengetahui siswa dengan nilai tertinggi dan terendah. Nilai siswa juga dijadikan sebagai penentu kelompok terbaik dalam kelas tersebut. Kelompok terbaik akan mendapatkan suatu penghargaan dari guru. Hal ini dimaksudkan untuk memotivasi siswa agar belajar dengan lebih baik, dan (2) Rencana Pelaksanaan Pembelajaran (RPP) yang digunakan sebagai panduan guru dalam melaksanakan pembelajaran di dalam kelas. Dalam penelitian ini RPP digunakan untuk memberikan perlakuan terhadap siswa yaitu dengan metode STAD.

Teknik pengumpulan data adalah Tes, Salah satu alat yang digunakan untuk mengetahui kemampuan peserta didik adalah tes. Tes yang digunakan dalam penelitian ini adalah tes subjektif. Tes Subjektif (essay) adalah tes uraian yang bentuk soalnya merupakan kaliamat pertanyaan ataupun perintah, sedangkan jawabannya dalam bentuk uraian,maupun penjelasan mengenai hasil pemikiran peserta tes sesuai dengan latar belakang dan wawasan pengetahuan yang dimiliki peserta didik (Ahmad Hamid,2009). Dalam penelitian ini, ada dua buah tes yang diberikan kepada siswa yaitu pre-tes dan posttest. Pre-test dibagikan sebelum siswa diberikan tindakan, atau sebelum mempelajari materi model pembelajaran kooperatif tipe stad bertujuan untuk melihat siswa memiliki kemampuan yang sama atau tidak. Sedangkan post-test dibagikan setelah siswa diberikan tindakan atau setelah mempelajari materi tersebut dengan model pembelajaran dengan kooperatif tipe stad bertujuan untuk mengetahui hasil belajar siswa.

Menurut Uzer Usman (2007: 64), Teknik Analisis Data, Bahwa ada terdapat kriteria ketuntasan belajar perorangan dan klasikal, yaitu: Pertama, Daya serap perseorangan; Seseorang siswa dapat disebut telah tuntas belajar bila ia telah mencapai skor $70 \%$ atau nilai 7.0. kedua, Daya serap kalsikal; Suatu kelas disebut tuntas belajar bila dikelas tersebut telah terdapat $8,5 \%$ yang telah mencapai daya serap $70 \%$. Presentase daya serap siswa (PDS) secara perorangan atau individual dihitung dengan rumus:

P DS $=\left(\mathrm{S}_{-}\left(\mathrm{y}^{\wedge}(\mathrm{)})\right)\right) / \mathrm{S} \_\left(\left[\operatorname{maks} \rrbracket^{\wedge}\right) \times 100 \%\right.$

Dimana:

PDS = Daya serap

S_( (y $\left.\rrbracket^{\wedge}\right)=$ skor yang diperoleh

S_ $\left(\llbracket \operatorname{maks} \rrbracket^{\wedge}(\right.$ ) $)=$ skor maksimal

Dengan kriteria:

$0 \%<$ PDS $<70 \%$ : siswa belum tuntas dalam belajar

$70 \% \leq$ PDS $\leq 100 \%$ : siswa telah tuntas dalam belajar

Dari uraian diatas dapat diketahui siswa yang belum tuntas belajar dan yang sudah tuntas belajar secara individu. Selanjutnya dapat juga diketahui apakah ketuntasan belajar secara klasikal telah tercapai, dilihat dari [presentasi siswa yang telah tuntas dalam belajar dapat dirumuskan sebagai berikut: 
$\mathrm{PKK}=\left(\mathrm{X}_{-}\right) / \mathrm{Y} \times 100 \%$

Dimana:

PKK = Presentase ketuntasan Klasikal

$\mathrm{X}_{-} \quad=$ Banyaknya siswa yang telah mencapai daya serap $\leq 70 \%$

Y_( ) = Banyaknya subjek penelitian

Dengan demikian, seorang siswa dikatakan tuntas jika PDS $\leq 70 \%$, sedangkan suatu kelas dikatakan tuntas jika $\mathrm{PKK} \geq 85 \%$.

Apabila hasil belajar siswa yang diperoleh pada siklus I sudah sesuai dengan ketuntasan belajar minimal yang telah ditetapkan yaitu $70 \%$ secara individual dan 85 $\%$ secara klasikal maka penelitian ini dinyatakan sudah berhasil dan tidak dilanjtukan kesiklus berikutnya. Dan sebaliknya apabila kemampuan siswa yang diperoleh belum selesai dengan ketuntasan belajar yang telah ditetapkan, mak penelitian dilanjutkan ke siklus berikutnya.

\section{HASIL PENELITIAN \\ Siklus I}

Tahap-tahap Penelitian Tindakan Kelas di siklus I meliputi: (1) persiapan yang dilakukan dengan pembuatan RPP menggunakan format yang telah disetujui sekolah, (2) pelaksanaan dilakukan dalam pembelajaran materi Infaq harta diluar Zakat yang dilakukan sesuai jadwal sekolah yaitu hari Senin menggunakan metode kooperatif tipe STAD maka terlebih dahulu membagi kelas menjadi beberapa kelompok kecil berdasarkan prestasi belajar, dan tiap kelompok harus memuat siswa laki-laki dan siswa perempuan, (3) observasi dimana dalam kegiatan ini, guru mengawasi jalannya diskusi, memimpin presentasi kelompok dan memberikan penilaian, dan (4) refleksi adalah tahapan dimana hasil penelitian dianalisis kemudian dilakukan tindakan koreksi terhadap kekurangan yang terjadi.

Hasil observasi di kelas adalah sebagai berikut: (1) terdapat kesuaian antara pembagian waktu di RPP dengan lembar observasi kelas, (2) ada satu aktifitas yang tidak dilakukan guru yaitu tidak mencatat siswa yang tidak membawa artikel sehingga belum ada reward dan punishment pada siswa supaya siswa lebih disiplin dalam pembelajaran, (3) presensi tidak harus satu persatu siswa karena sudah cukup mengenal siswa. Masing-masing kelompok kecil berusaha memperoleh skor kelompok untuk mendapat penghargaan sebagai tim terbaik. Skor kelompok diperoleh dari akumulasi skor setiap anggota kelompok. Rerata nilai kelas di siklus pertama ini sebesar 60 dengan nilai tertinggi 8.0 dan nilai terendah 40. Siswa belajar lebih menyenangkan karena terjadi kompetisi antar siswa dan juga kompetisi antar kelompok. Persentase menunjukan bahwa hanya $25,64 \%$ dengan jumlah siswa 10 orang yang tuntas dan tidak tuntas $74,35 \%$ dengan jumlah siswa 29 Orang dalam tes awal yang diberikan. Hal ini dijadikan sebagai pembelajaran lanjutan untuk menyusun rancangan pembelajaran yang akan dilakukan di siklus I, dengan menggunakan model pembelajaran Kooperatif tipe STAD

Siklus 1 ,dapat disimpulkan bahwa presentase keaktifan siswa 54,17. Maka diperlukan peningkatan proses pembelajaran, sehingga diharapkan siswa semakin aktif dalam mengikuti proses pembelajaran. Analisis Data 1, Di akhir pelaksanaan siklus 1 siswa diberikan tes hasil belajar mengenai kemampuan siswa dalam menyelesaikan soal pada materi infak harta diluar zakat yang bertujuan untuk mengetahui keberhasilan tindakan yang diberikan. Adapun hasil tes belajar siklus 1 adalah sebagai berikut:

Deskripsi Hasil Tes belajar Siswa Pada Siklus 1 sebagai berikut.

a. Jumlah siswa yang tuntas $=21$ orang

b. Jumlah siswa yang tidak tuntas $=18$ orang

c. Persentase Ketuntasan Klasikal $(\mathrm{PKK})=$ $\frac{21}{39} \times 100=53,84 \%$

d. Persentase yang tidak tuntas $=\frac{18}{39} \times 100=$ $46,15 \%$

e. $\quad$ Rata - rata Kelas $=73,33$

Deskripsi Ketuntasan Tes Hasil Belajar Siklus 1 Siswa ,Dari hasil persentase diatas diketahui siswa yang tuntas berjumlah 21 orang, dengan persentase ketuntasan klasikalnya $53,84 \%$. Sedangkan siswa yang tidak tuntas berjumlah 18 orang dengan persentase $46,15 \%$ dengan rata - rata kelas 73,33 .

\section{Siklus II}

Pada pembelajaran kooperatif tipe STAD guru dan siswa harus displin dalam melaksanakan setiap tahapan.Dalam hasil observasi siswa pada siklus II, dapat disimpulkan bahwa presentase keaktifan siswa 93,18. Dan dapat disimpulkan bahwa aktifitas siswa selama pelaksanaan pembelajaran kooperatif tipe STAD berjalan dengan kategori 
sangat baik. Analisis data II, Diakhir pelaksanaan siklus II siswa diberikan tes hasil belajar mengenai kemampuan siswa dalam menyelesaikan soal pada materi infak harta diluar zakat yang bertujuan untuk mengenai keberhasilan tindakan yang diberikan. Adapun hasil tes hasil belajar siklus II adalah sebagai berikut: Dilihat dari data hasil Tes Siklus II diatas, maka:

a. Jumlah siswa yang tuntas $=34$ orang

b. Jumlah siswa yang tidak tuntas $=5$ orang

c. Persentase Ketuntasan Klasikal $(\mathrm{PKK})=$ $\frac{34}{39} \times 100=87,17 \%$

d. Persentase yang tidak tuntas $=\frac{5}{39} \times 100=$ $12,82 \%$

e. $\quad$ Rata - rata Kelas $=80,25$

Deskripsi Ketuntasan Tes Hasil Belajar II Siswa, Dari hasil persentase diatas diketahui bahwa siswa yang tuntas berjumlah 34 orang, dengan persentase ketuntasan klasikalnya 87,17. Sedangkan siswa yang tidak tuntas berjumlah 5 orang dengan persentase 12,82 dengan rata - rata kelas 80,25.

Adapun perbandingan nilai keaktifan Belajar dan hasil belajar siswa pada siklus pertama, dan kedua disajikan Gambar dan Tabel-tabel berikut ini.

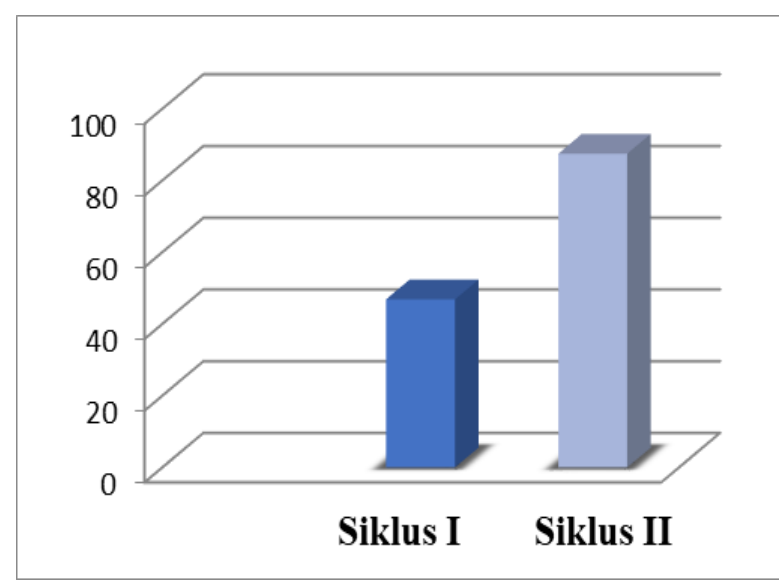

Gambar 1. Diagram Peningkatan Keaktifan Belajar Siswa Dari Siklus I ke Siklus II

Dari diagram diatas dapat dilihat bahwa ada peningkatan keaktifan belajar siswa dari siklus I ke siklus II. Pada siklus I, siswa aktif sekitar 54,17 \% dan pada siklus II, siswa yang aktif sekitar 93,18\%. Dengan demikian terjadi peningkatan persentase keaktifan siswa sebesar $39,01 \%$.

Tabel 1. Peningkatan Hasil Belajar Siswa pada Siklus I dan Siklus II

\begin{tabular}{llccccc}
\multirow{2}{*}{ Kategori } & \multicolumn{2}{c}{ Nilai Pre Test } & \multicolumn{2}{c}{ Nilai Hasil Belajar } & \multicolumn{2}{c}{ Silai Hasil Belajar I } \\
\cline { 2 - 7 } & \multicolumn{1}{c}{ Angka } & Persen & Angka & Persen & Angka & Persen \\
\hline Nilai $\geq 70 \%$ & 10 Orang & $25,64 \%$ & 21 Orang & $53,84 \%$ & 34 Orang & $87,17 \%$ \\
\hline Nilai $<70 \%$ & 29 Orang & $74,35 \%$ & 18 Orang & $46,15 \%$ & 5 Orang & $12,82 \%$ \\
\hline Rata - rata & $60 \%$ & & $73,33 \%$ & & $80,25 \%$ & \\
\hline PKK & $25,64 \%$ & & $53,84 \%$ & & $87,17 \%$ & \\
\hline
\end{tabular}

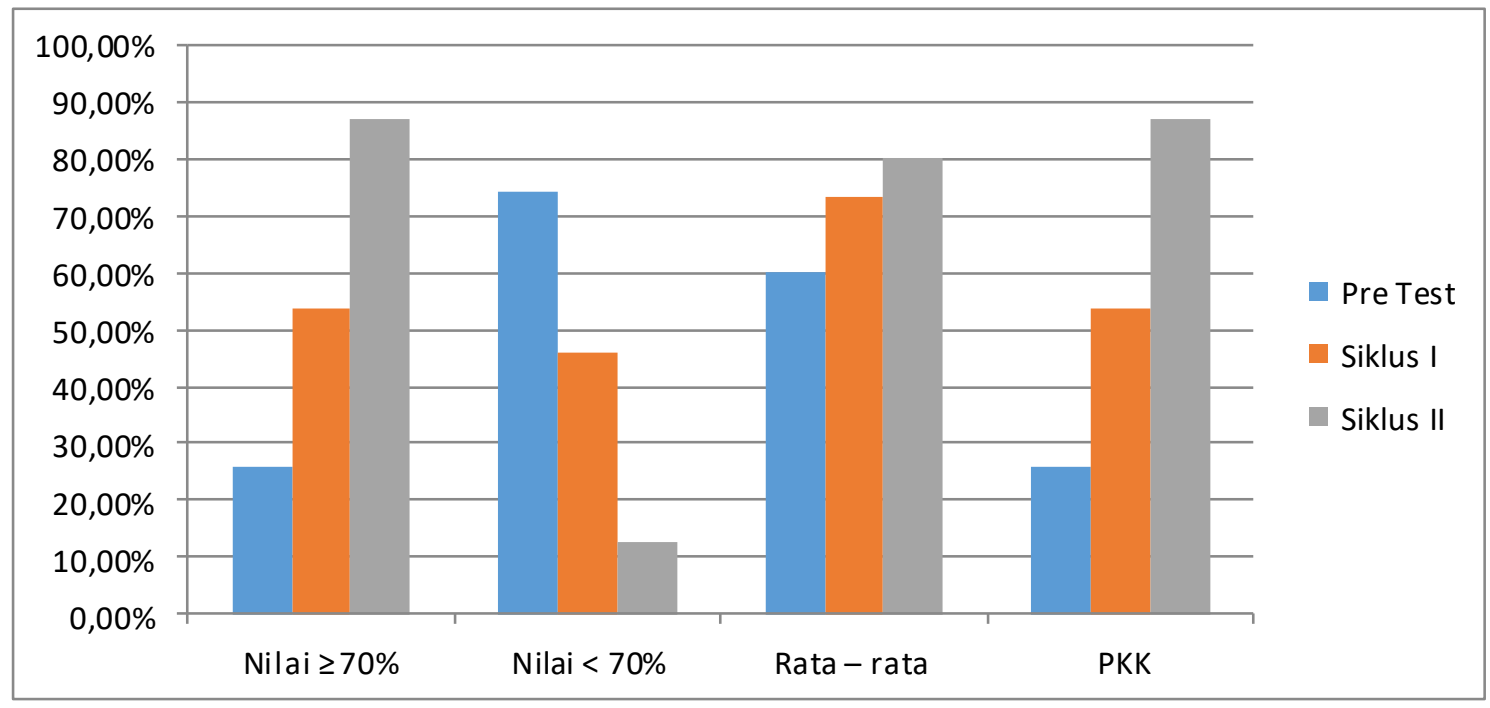




\section{Gambar 2: Diagram Peningkatan Hasil Belajar Siswa pada Siklus I dan Siklus II}

Dari tabel dan diagram di atas dapat dilihat bahwa ada peningktan hasil belajar siswa antara sebelum tindakan, siklus I dan siklus II. Hal ini dapat dilihat dari: pertama, Pertambahan dari nilai rata-rata kelas Nilai rata - rata pre test adalah $60 \%$ dan pada tes hasil belajar I adalah $73,33 \%$, maka pertambahan nilai rata - rata $13,33 \%$. Pada tes hasil belajar II nilai rata - rata yang diperoleh adalah 80,25 . Jika dibandingkan dengan nilai pre test maka diperoleh 20,25 \%. Sedangkan dengan hasil belajar II maka diperoleh pertambahan rata rata sebesar 6,92. Kedua, Pertambahan jumlah siswa yang memperoleh nilai $\geq 70 \%$ Pada pre test siswa yang memperoleh nilai $\geq 70 \%$ berjumlah 10 orang sedangkan jumlah siswa yang memperoleh Nilai $<70 \%$ berjumlah 29 orang. Pada test hasil belajar siklus I, siswa yang memperoleh nilai $\geq 70 \%$ berjumlah 21 orang, sedangkan jumlah siswa yang memperoleh nilai $<70 \%$ berjumlah 18 orang. Itu berarti terjadi peningkatan jumlah siswa yang tuntas sebanyak 11 orang dari pree test awal ke siklus I. Pada test hasil belajar siklus II siswa yang memperoleh nilai $\geq 70 \%$ berjumlah 34 orang, sedangkan jumlah siswa yang memperoleh nilai $<70 \%$ berjumlah 5 orang. Ini berarti terjadi peningkatan siswa yang tuntas sebanyak 13 orang dari siklus I, sedangkan jika dibandingkan dengan pree test awal peningkatan jumlah siswa yang tuntas sebanyak 24 orang. ketiga, Peningkatan persentase ketuntasan klasikal Pada pree test persentase ketuntasan klasikal sebesar 25,64 \% sedangkan pada siklus I persentase ketuntasan klasikal sebesar 53,84\% dan pada siklus II persentase ketuntasan klasikal sebesar 87,17\%. Dengan demikian pada siklus I mengalami peningkatan $28,2 \%$ dari pree test awal dan pada siklus II mengalami peningkatan sebesar $33,33 \%$ dari siklus I

Dalam penelitian ini, penggunaan model pembelajaran kooperatif tipe STAD memberi pengaruh yang signifikan dan peningkatan terhadap hasil belajar siswa pada materi infak harta diluar zakat. Dari hasi tes awal (pre test) di kelas VIII persentase ketuntasan klasikal diperoleh 25,64 \% (10 siswa) sedangkan persentase yang tidak tuntas $74,35 \%$ (29 siswa) dengan rata - rata kelas 60 $\%$. Setelah pemberian tindakan pembelajaran dengan menggunakan model pembelajaran kooperatif tipe STAD, hasil tes belajar I persentase ketuntasan klasikal 53,84 \% (21 siswa) sedangkan persentase yang tidak tuntas $46,15 \%$ (18 siswa) dengan rata 73, $33 \%$. Dan setelah dilakukan perbaikan dari siklus I, maka pada siklus II diperoleh hasi tes belajar II yang persentase ketuntasan klasikal 87,17 \% (34 siswa) sedangkan persentase yang tidak tuntas $12,82 \%$ (5 siswa) dengan rata - rata $87,17 \%$.

Hal ini didukung oleh berbagai faktor antara lain guru membentuk kelompok siswa sesuai dengan tingkat kecerdasan secara merata dan aktifitas guru yang selalu berusaha membuat siswa tetap semangat dan lebih aktif dalam kegiatan pembelajaran. Selain itu, berdasarkan hasil wawancara kepada beberapa orang siswa bahwa mereka merasa senang diajar dengan model pembelajaran kooperatif tipe STAD ini sangat menyenagkan, seru, dan asyik karena siswa dapat mencari jawaban secara bersama dan bisa memilih jawaban yang sudah ada. Sehingga dengan demikian siswa merasa gembira dalam mengikuti proses pembelajaran dan proses pembelajaran berlangsung dengan menyenangkan. Peneliti berpendapat bahwa materi yang disajikan dengan menggunakan model pembelajran tipe STAD memberikan suasan baru dalam belajar, dimana dalam pembelajarannya siswa diajak dalam suasana yang menyenangkan dan tidak monoton dan membosankan serta menimbulkan antusias siswa dalam memahami materi. Ini sebabnya hasil belajar siswa dapat ditingkatkan dengan model pembelajaran kooperatif tipe STAD. Berdasarkan hasil penelitian ini, pembelajaran dengan menggunkan model pembelajaran kooperatif tipe STAD dapat meningkatkan hasil belajar siswa kelas VIII SMP Al-Hidayah Medan pada mater Infak harta diluar zakat.

\section{PENUTUP}

Berdasarkan data dan pembahasan yang diperoleh, maka dalam penelitian ini dapat disimpulkan bahwa pembelajaran kooperatif tipe STAD mampu meningkatkan hasil belajarn siswa. Beberapa hal yang perlu diperhatikan antara lain penentuan siklus penelitian harus disesuaikan dengan target yang ingin dicapai, perlu diperhatikan rotasi kelompok yang sebaiknya dilakukan setelah 3-5 kali pertemuan, sehingga pelaksanaan pembelajaran kooperatif tipe STAD memerlukan waktu yang lebih lama. Penelitian ini menunjukkan bahwa 
pembelajaran kooperatif tipe STAD mampu meningkatkan hasil belajar siswa pada Standar Kompetensi Infak Harta Diluar Zakat. Berdasarkan simpulan dan implikasi diatas berikut ada beberapa saran untuk peningkatan keaktifan dan hasil belajar siswa menggunakan pembelajaran kooperatif tipe STAD antara lain: (1) Kepada siswa, untuk lebih sering terbuka kepada guru maupun teman, karena pembelajaran bukan proses yang dikerjakan individu melainkan adanya interaksi anata guru dan murid serta murid dengan murid. (2) para guru setidaknya menerapkan model pembelajaran kooperatif tipe STAD dan tidak hanya berfokus pada satu model atau pun metode pembelajaran saja, sehingga siswa dapat lebih aktif dalam mengikuti kegiatan belajar mengajar. Serta melihat apa yang dibutuhkan dan diminati oleh siswa dalam proses belajar, sehingga memungkinkan hasil belajar siswa juga dapat meningkat. dan (3) Kepada peneliti yang berminat melakukan penelitian dengan menggunakan model pembelajaran yang sama dengan peneliti, disarankan agar mengembangkan penelitian ini dengan materi yang lain sehingga dapat pula membedakan hasil peningkatan belajar pendidikan agama Islam tidak hanya pada materi infak harta diluar zakat saja. Selain itu, dapat dilakukan dalam skala yang lebih besar dan pembelajaran teori beserta praktik. Dari hasil penelitian tersebut maka dapat disimpulkan bahwa pembelajaran kooperatif tipe STAD mampu meningkatkan hasil belajar siswa hingga memenuhi Kriteria Ketuntasan Minimal (KKM).

\section{DAFTAR PUSTAKA}

Ibrahim, D. (2013). Penerapan Fikih 2 untuk SMP/MTS kelas VII (KTSP). Solo: Aqila.

Lie, A. (2002). Cooperative Learning: Mempraktikan Cooperative Learning di Ruang- Ruang Kelas. Jakarta: PT Gramedia Widiasarana Indonesia.
Maragustam. (2010). Filsafat Pendidikan Islam. Yogyakarta: Kurnia Kalam Semesta.

Mujiono \& Damayanti. (2006). Belajar dan Pembelajaran. Jakarta: Rineka Cipta.

Nata, A. (2001). Tafsir ayat-ayat pendidikan "tafsir al-ayat tarbawiy". Jakarta: PT.Raja Grafindo Persada.

Rusman. (2011). Model-model Pembelajaran Mengembangkan Profesionalisme Guru, Bandung: PT Raja Grafindo Persada.

Sanjaya.W. (2010). Strategi Pembelajaran Berorientasi Standar Proses Pendidikan,"cetakan ke-7", Jakarta: Kencana prenada Media Group.

Slavin, R.E. (2005). Cooperatife Learning. Bandung : Nusa Media.

Slameto. (1995). Belajar dan faktor faktor yang mempengaruhinya. Jakarta: PT Rineka Cipta. Suryabrata,

Siddik, D. (2011). Konsep Dasar Ilmu Pendidikan Islam. Bandung: Citapustaka Media Perintis.

Susilana. (2007). Media Pembelajaran. Bandung. CV Wacana Prima

Suparno, A. Suhaenah. (2001). Membangun Kompetensi Belajar. Dirjen Pendidikan Tinggi Depdiknas.

Syah, M. (2004). Psikologi Pendidikan: dengan pendekatan baru. Bandung: PT Remaja Rosdakarya.

Trianto. (2010) Mendesain Model Pembelajaran Inovatif - Progresif. Surabaya: Kencana Prenada Media Group

Usman, U. (2007). Menjadi Guru Profesional. Bandung: PT Remaja Rosdakarya.

Wiriaatmadja, R. (2007). Metode Penelitian Tindakan Kelas,. Bandung: PT Remaja Rosdakarya. 